\title{
Restarting after Business Discontinuity among Bumiputra Small and Medium Enterprises
}

\author{
Azlina Mohamad \\ azlina@mara.gov.my \\ Adriana Mohd. Rizal \\ adriana.kl@utm.my \\ Farzana Quoquab \\ farzana@ibs.utm.my, \\ International Business School, Universiti Teknologi Malaysia \\ Noor Hasni Juhdi \\ n_hasni@ukm.edu.my_and \\ Faculty of Economic and Business, Universiti Kebangsaan Malaysia \\ Musli Sahimi \\ Graduate School of Business, Universiti Kebangsaan Malaysia \\ musli.sahimi@gmail.com
}

Abstract

\begin{abstract}
Small and Medium Enterprises (SMEs) entrepreneurial activities are critical to nation's economic development and wealth creation. The governments provide both financial and non-financial assistances to support the development of these firms. Despite the government assistance, SMEs experience business discontinuity at the early stage of the firm development and unable to bounce back. Research on restarting after business discontinuity among SMEs is vital to enrich the existing literature in regards to firms' learning and survival ability, and improving their current strategy to compete and sustain in the market. The objective of this study is to identify the factors that contribute to restarting after business discontinuity among Bumiputra Small and Medium Enterprises. This study utilized the case study methodology and selected Bumiputra firms under Majlis Amanah Rakyat as the research setting. The study found that five factors, including personality, environment, internal factor, resilience, and spiritual belief contributed to restarting after business discontinuity among Bumiputra SMEs. These findings broaden the theory of firm failure in entrepreneurship studies and their relations to firm learning. These insights are useful for both entrepreneurs of new firms and policy makers to improve entrepreneurial learning in supporting firms' survival.
\end{abstract}

Keywords: Entrepreneurship, firms' failures, business discontinuity, personality, environment, internal, resilience, and spiritual belief

\section{INTRODUCTION}

The business activities of Small and Medium Enterprises (SMEs) are vital for nations' economic development and wealth creation (Sebora, Lee, and Sukasame, 2009; Global Entrepreneurship Monitor, 2013). However, many SMEs failed to bloom and experience business discontinuity before their third anniversary (Global Entrepreneurship Monitor, 2013). A study by Inyang and Enuoh (2009) found a high rate of entrepreneurs' failures in the face of governments' encouragement, financial assistance, and supports.

It is important to highlight that most firms' failures were small businesses and the failures occurred in the early stages of firm development. Reiss (2015) found that the failure rate of small businesses within the first five years was more than 50 percent. A study by Malaysian government agency revealed that most entrepreneurs had experienced business discontinuity at least once in the life time (Mason, 2015). The Global Entrepreneurship Monitor (2013) suggested sustainment of new entrepreneurs in the early development stages to avoid failure or business discontinuity.

Although firm's success has received significant research attention, the present knowledge about business discontinuity remains scant. In particular, the understanding of "how firm learn from failure, and restart their businesses" is inadequate. 
Considering this, present research attempts to identify the factors that lead to restarting after business discontinuity among Bumiputra Small and Medium Enterprises in Malaysia. Not surprisingly, the studies related to SMEs predominantly focus on the firms' success than the firms' failure (Chittithaworn, Islam, Keawchana, and Yusuf, 2011; Minniti and Bygrave, 2001; $\mathrm{Ng}$ and Kee, 2012; Simpson, Tuck and Bellamy, 2004; Song, Podoynitsyna, Van Der Bij, and Halman, 2008). Research on firms' failure, particularly on restarting a business after business discontinuity among the SMEs is important to understand firms' learning and survival ability, and to improve their current strategy to compete and sustain in the market (Cope, 2011). Other researchers believe that failure should be interpreted in positive term rather than a negative one (Smith and McElwee, 2011). From a policy standpoint, failure of SMEs is an important area to focus, as there is a lack of policy formulated against entrepreneurs' failures and recovery (Storey, 1994). As such, there is a need to answer the question: "what factors contributed to SMEs' ability to restart their businesses after business discontinuity?" The present study is an effort to fill this gap in the literature.

The rest of the paper is organized as follows. In the next section, theoretical underpinning is discussed followed by methodology utilized in this study. Case study approach has been discussed further along with results and discussion. Finally, implications, conclusion and future research directions are also highlighted.

\section{THEORETICAL BACKGROUND}

\subsection{Underpinning Theories}

This study is underpinned by entrepreneurship theory, entrepreneurship psychological theory and entrepreneurship motivation theory.

\subsubsection{Entrepreneurship Theory}

Entrepreneurship refers to entrepreneurial activity in which firms through their entrepreneurs take chances without being tied to available resources (Stevenson and Jarillo, 1990). Entrepreneurs develop resources through learning and synergistic (Burgelman, 1983; Kuratko and Welsch, 2001; Leibstein, 1968; Stewart, 1989; Venkatraman, McMillan and McGrath, 1990). Entrepreneurship entails entrepreneurs in promoting change and innovation expressed through new combinations of resources, and introducing new methods of doing business (Burgelman, 1983; Schumpeter, 1934). All definitions of entrepreneurship imply actions. Thus, entrepreneurship implies that entrepreneurs act to change the market and this often comes about detecting and establishing the opportunities (Schumpeter, 1935). In summary, the entrepreneurs are active actors in the market.

The actions of the entrepreneurs are related to the psychological and motivational factors to start an organization (Gartner, 1989). Entrepreneurship also involves discovery, evaluation, and exploitation of opportunities (Shane and Venkatraman, 2000). In the book of The General Theory of Entrepreneurship, Shane (2003) outlines view general theory and label it as 'individual opportunity nexus' approach. This approach is also known as the 'Discovery Theory of Entrepreneurship' (Shane, 2003). There is an alternative general theory of entrepreneurship called the 'Creation Theory of Entrepreneurship' (Anderson, 2005; Venkatraman, 2003). All of these theories related to human actions towards the entrepreneurial activity.

\subsubsection{Entrepreneurship Psychological Theory}

Entrepreneurial psychological is part of the entrepreneurial actions in formulating strategies for organization's success (Dess, Lumpkin, and Covin, 1997). Entrepreneurs gained competitive advantage by implementing entrepreneurial actions through innovation and risk-taking (Miller and Friesen, 1982). Miller (1983) proposed a theory of entrepreneurship action by combining actions of an organization through innovation, risk taking, and acts proactively. Another important variable in entrepreneurship activity is self-efficacy. Self-efficacy has become a highly effective predictor for motivation and learning for the past two decades (Zimmerman, 2000). Schwarzer (2014) argues that entrepreneurs who beliefs that they can take actions to solve some problem are better off and cope well with setbacks including business discontinuity. 
Proactive attitude is closely related to the discovery and creation of new resources in the niche (March, 1991; Lumpkin and Dess, 2001). Innovation is the root in the entrepreneurial process (Schumpeter, 1934; Drucker, 1985). Self-efficacy is the one's ability to implement necessary resources, competencies and skills to achieve a certain level of achievement (Bandura, 1977). The concept of risk-taking by Brockhaus (1980) is associated with an entrepreneurial process when a firm is always ready to engage in risk-taking in business after making certain arrangements. This concept means that the firm is always willing to engage with a number of commitments to specific resources to achieve higher returns on the transactions that are not identified and novel (Brockhaus, 1980; Miller, 1983; Lumpkin and Dess, 1996).

\subsubsection{Entrepreneurship Motivation Theory}

Motivation plays an important part in the entrepreneurial activity. The entrepreneurship motivation theory relates to the internal and environmental factors of entrepreneurial activity. Generally, firms' entrepreneurial activities were surrounded by elements that interacted and affected entrepreneur's decision-making and behaviour (Shane, Locke and Collins, 2003). Aldrich and Zimmer (1986) suggest that a business can be viewed from internal and environmental factors. Specifically, according to Murphy, Trailer, and Hill (1996), firms' internal performances were measured by financial efficiency, growth, profitability, size, liquidity, success or failure, market share, and leverage.

The environment includes political factors, market forces, technology regime, market size and potential barriers to entry (Baumol, 1990). The political factors are such as legal restrictions, quality of law enforcement, political stability, and currency stability (Baum et al., 2001). The market forces are the structure of the industry and population demographics. This motivation theory includes resources in the entrepreneurship action (Locke, 2000). The resources are available in term of capital, labour, infrastructure, and technology (Lumpkin and Dess, 1996; 1997). Researcher agreed that the categories of internal and environmental factors influence the entrepreneurial process (Shane and Venkantraman, 2000).

\subsection{Business Discontinuity and Restarting Businesses}

According to Ulmer and Neilson (1947) as cited in Stanton and Tweet (2009), business discontinuity exists because of personal reasons such as illness or death of business owner, retirement, or selling the business to make profit. Failure was also associated with bankruptcy, insolvency, crisis, trouble, decline in performance, liquidation, project failure, distress, crashing, accounting practices, system failure, and being non-performance (Corbin and Strauss, 1990). McKenzie and Sud (2008) defined entrepreneurs' failures as a diversion from the entrepreneur's desired objectives and expectations. On the other hand, Hisrich, Peters, and Shepherd (2005) referred failure in terms of personal emotion associated with frustration, anxiety, hard work, and enthusiasm. Friedman (2004) stated that entrepreneurs who were overwhelmed with feelings of reduce self-esteem and incompetence, could quit from innovating and creating new ideas. More studies are needed to study business discontinuity among SMEs (Inyang and Enuoh, 2009; Gaskill, Van Auken and Manning, 1993; Pretorius, 2008; Shepherd, 2003; Jim and John, 1996) especially in the area of restarting from business discontinuity.

The Global Entrepreneurship Monitor (2013) defines business discontinuity as firms' failures that decrease the economic growth in the early development stages. The study also found that business discontinuity is related to unprofitable businesses and problems in obtaining financing. Most of firms' failures led to serious financial difficulty that caused insolvency, business discontinuity, (Liou and Yang, 2008; Shepherd, 2003) and bankruptcy (Global Entrepreneurship Monitor, 2013; Liou and Yang, 2008; McGrath, 1999; Shepherd and Haynie, 2011; Zacharakis, Meyer and De Castro, 1999). Studies on firms' failures were not widespread and less reviewed which required extended research (Pretorius, 2008; Shepherd, 2003). Scholars asserted that understanding business failure provides businesses with knowledge through learning of others experiences (Carter and Van Auken, 2006; Hamrouni \& Salem, 2013; Pretorius and Le Roux, 2011; Ucbasaran, Shepherd, Lockett and Lyon, 2013). Thus, more studies are needed on firms' failures (Global Entrepreneurship Monitor, 2013; Pretorius, 2008; Shepherd, 2003; Singh, Corner and Pavlovich, 2007), specifically on how they restart after experiencing business discontinuity (Hamrouni and Salem, 2013; Ucbasaran et al., 2013).

\subsection{Factors Contributing to Restarting after Business Discontinuity among SMEs}




\subsubsection{Personality Factors}

Korunka, Leuger and Mugler (2003) argued that entrepreneur personality is vital for entrepreneurial intentions to start a new business and success. Benson and Han, 2011) argued that personality characteristics could influence the quality of decision making. This includes the decision to restart businesses after business discontinuity. The entrepreneurial personality is described as a specific pattern of more action-related characteristics (Korunka et al., 2003). McGrath's (1999) study focused on the human elements such as entrepreneur's personality, traits, and qualities. In this study, personality refers to proactive, self-efficacy, innovative and risk-taking (Bandura, 1977; Miller, 1983; Schwarzer, 2000; Zimmerman, 2000).

\subsubsection{Internal factors}

Rozell et al. (2010) stated that internal factors of entrepreneurs are associated with elements such as business resources, motivated entrepreneurs, industry knowledge, technology, planning skills, communication skills, interpersonal skills and risk taking. Awais and Manzoor Arain (2011) added two internal factor which are start up planning and learning from business failure. While, Azmi, Nik Hairi, Lee, and Fauziah (2012) argued that professional coaching is important as one of the internal factors. However, Audet and Couteret (2012) argued that successful entrepreneurs enjoy coaching in running the business, while entrepreneurs that experienced business failure desire consultation rather than coaching. Thus, theses internal factors influence firms' success as well as failure. Over the years, various studies on internal factors focus on the management, resources, operations but little study on the financial needs (Abdullah, Hamali, Rahman Deen, Saban, and Zainoren, 2009; Liou and Yang, 2008). The financial need is essential for entrepreneurial activities and business grows (Liou and Yang, 2008). In this study, internal factors refer to management, human resource, operational, production and financial aspects.

\subsubsection{External factors}

Finally, Chen (2010) found that the main factor that influenced entrepreneurial activity was environment. Environment is defined as the factors that affect the social dynamics of the situation (Abdullah, et al., 2009). Environment plays an important role in influencing the actions of an individual. The environment elements included changes in politics environment (Foster and Dye, 2005), government policies and bureaucracy (Abdullah, et al., 2009), poor market conditions (Shepherd, 2003), positions of the overall economy (Abdullah, et al., 2009), negative societal attitude (Strotman, 2006 as cited in Singh, 2011) and the latest technologies (Wanberg and Banas, 2000). In addition, firms also faced other pressures such as recession, internet crime, imitation and extreme weather conditions (Taylor and Thorpe, 2004; Sheffi and Rice Jr., 2005). In this study, environment factor is defined as the political, economic, social and technologies changes.

\section{RESEARCH METHODOLOGY}

This study employed an explanatory case study methodology to examine the factors that lead to restarting a business among Bumiputra SMEs after experiencing business continuity. Following the eight steps in the theory development process, as in Eisenhardt (1989) and Yin (2009), the study established the research question, which is "What factors that lead to business discontinuity? The case study protocol containing the interview questions was developed and in-depth interviews were conducted with four founders who are also the lead entrepreneurs of Bumiputra SMEs. The case was developed in a chronological format and data were analyzed using the time-based and stage-based analysis method. Then, the theoretical propositions and analytic generalization were established. The identification of variables that influenced the restarting after business discontinuity was also being recognized. Finally, the model and construct development are iterative and comparison between the findings of the study and literature is necessary to establish internal validity.

\section{CASE STUDY}

This section provides a brief description of each case.

\subsection{Case No. 1: Fatihah Frozen Food Pvt. Ltd.}

Mrs Fatihah Anis Ibrahim (subsequently known as Mrs Fatihah) founded Fatihah Frozen Food Pvt. Ltd. (FFF) in 1994. The business started as a home based business specialized in frozen food. The products of FFF were Malaysian pastry and 
delicacies. In 1994, FFF obtained its first initial capital of RM200, 000 through SME Bank and operated at the industrial area at Selaman, Bangi. The location was not suitable for a food factory and in 1997, FFS moved to Taman Industri Sri Haneco, Semenyih, Kajang with ten staffs. Using the loan facility from SME Bank, Mrs Fatihah purchased food processing machinery and equipment.

There was a recession in 1997 and production was dramatically reduced. FFF suffered a huge loss. The business was faced with a closure if failing to repay the loans. The machinery and factory equipment had to be sold, and the operation stopped. However, the sales of the machinery and factory equipment ware were well below its purchase price, which resulted in substantial losses and FFF nearly became insolvent.

To continue the business, in 1998, Mrs Fatihah applied for and received a recovery grant of RM50,000 from Majlis Amanah Rakyat (MARA) - government agency that help Bumiputra (native) entrepreneurs. Six months later, FFF received an additional working capital of RM195,000 from MARA. The economy picked up in 1998 and the business once again became profitable. In 2010, MARA offered FFF to move to its food industrial area located in Batu Caves, Selangor with an affordable of RM5,000 monthly rent with two plus two years renewal contract. Started with five staff, FFF had now hired 20 staffs.

From 1994 to 2014, FFF had received nearly RM1 billion in term of government financial and non-financial assistances. The assistance came from SME Bank, MARA and TEKUN. The supports included training, advisory, and business grant. In 2010, FFF was awarded with Good Manufacturing Practice (GMP) and HACCP certifications.

\subsection{Case No. 2: Safa Bakery and Cafe}

Ikhwan Bakery was a long-established, family-owned bakery business. At one time, Ikhwan Bakery had five bakery shops and kiosks in all the main towns such as Langkawi, Pantai Dalam, Pantai Baru, Bangsar, and Batu Caves.

Over the period from 1996 to 2008, the firm's performance deteriorated and its profits dwindled. The management did not look for reasons of dwindling firm's performance and took no decisive steps to win back the business, which was steadily losing. The management's only serious response to the firm declining sales and turnover was to consolidate its resources and assets. The management closed the other four bakery shops, and left with one shop in year 2000. Things got worse, the entrepreneur Mr Ikhwan was faced with a lots of personal liability and he was declared a bankrupt in 2011.

In 2012, Mrs Sharifah, wife of Mr Ikhwan, decided to take over Ikhwan Bakery to save the bakery shop. This was due to her affection for bakery business that she had built together with the husband for 18 years. In the beginning, she sought help from her friends to raise capital. Mrs Sharifah persuaded her friend, Mrs Siti Fatimah, to be a business partner in running the bakery business. Mrs Siti Fatimah agreed and she gave in RM25, 000 for initial capital. Several months later after realising that she had limited experience in the business, Mrs Sharifah sought business advice from MARA. One of MARA suggestions was to change the bakery name after bad reputation of Ikhwan Bakery. Ikhwan Bakery changed its name to Safa Bakery and Cafe in September 2012.

Safa Bakery and Cafe produced more than twenty varieties of bread and pastry. The firm's specialties were chocolate doughnuts, cream puff, chicken roll and tuna bread. In June 2014, MARA approved RM100, 000 loans for Safa Bakery under its Entrepreneur Technical Program. The loan facility helped Safa Bakery to improve its processing ability in order to compete in a wider market.

\subsection{Case No. 3: Sharifah Norizan's Boutique}

Mrs Sharifah Norizan owned a boutique business located at MARA Hall, Kuala Lumpur. The boutique shop was established in 2001 and run for a few years without significant commercial success. The boutique specialised in sewing men and women traditional clothing. The boutique received orders from individuals, government agencies, and non-government organizations (NGO). In 2004, the boutique added two more staffs and achieved a profit margin of 40 percent per year. Since that, business started to grow but she needed to invest in new sewing machines due to customers' requirement. Mrs Sharifah sought help from TEKUN (government agency in providing micro loan) and received RM3,000 loan facilities for sewing machine. 
In 2005, Mrs Sharifah was hit by a series of personal problems. At the height of it, she drained up her saving and ended up her marriage. Unable to pay for shop rental, she decided to close down the boutique. However, she continued to take orders from customers and worked from home. On weekdays, she had taken another job at a hotel to supplement the income.

In 2011, she remarried and started the boutique business again. Using her own saving, she rented one of MARA business premises. To upgrade her business knowledge, she attended related training programs regularly in sewing, motivational, and entrepreneur development organized by MARA. To date, Mrs Sharifah had coached three of her staffs and opened up two new branches.

\subsection{Case Study 4: Dianty Photo Enterprise}

Dianty Photo Enterprise (Dianty Photo) enjoyed 30 percent of profit margin since 1988 specializing in photography business. In 1990, the trend shifted to digital photography. At the time, its sole supplier, Kodak, was unable to keep pace with the changing technology shifting from film to digital photography. With less order on film photography, Dianty Photo was unable to generate positive cash flow and had to stop operation for six months. Believed that she can bounce back, Ms Dianty resumed and re-strategized the business later that year. In 1995, Dianty Photo received RM30, 000 loans from MARA to purchase digital photography equipment. Dianty Photo also established technical collaboration with two suppliers, Fuji and Canon in year 2000.

Ms Dianty realized that Dianty Photo had few new customers. In 2010, Ms Dianty planned to diversify her business. With starting capital of RM40, 000, Dianty Photo then transformed into a learning centre known as Dianty Academy. Dianty Academy offered certification courses in photography and to date, the academy had trained 420 photographers. She believed that Dianty Academy's quality in learning would give an edge to compete in the market.

\section{RESULTS AND DISCUSSIONS}

The study found that personality, environment and internal factors contribute to restarting after business discontinuity among Bumiputra Small and Medium Enterprises. Two new factors which are resilience and spiritual belief were also identified as factors that lead to restarting after business discontinuity.

\subsection{Personality Factor}

All cases were seen proactive in taking steps to restart business. All cases viewed business discontinuity in a more positive way and this led them to be more proactive after restarting the business. In addition, Case 1 and Case 4 admitted to have more confidence in their ability to run a business successfully because of the business discontinuity. Case 2 did not have the confidence at first when restart the business. Her partner helped her to facilitate and restart the business. In term of innovativeness, all cases found new ideas for their business. In addition, some cases were seen to rely more on informal way such as observation and past experiences. Case 1 and 2 frequently came up with new recipes for their products by observing or customer request. In term of self-efficacy, all the cases had the ability to recognise their strengths in knowing what could go wrong in a business and what to do when business discontinued. Case 1, 3 and 4 admitted that they were willing to take risk in the future. They believed that experiencing business discontinuity made them more confident in their ability to deal with any circumstances in future. Case 1,2 and 3 also perceived themselves as more mature and wiser after having gone through with business discontinuity.

\subsection{Environment factor}

Changes in the environment presented opportunities to all the cases. With National Development Policy (1990-2000) was in place, variety of supporting mechanisms and policies were established to assist entrepreneurs. These include funding, business grant, physical infrastructure, entrepreneurship programs, and business advisory services. In the Ninth Malaysia 
Plan (2006-2010), SMEs' development were given top priority included improving Bumiputera SMEs entrepreneurial and technical capabilities. Through MARA, all the cases benefited from the ongoing policy. With financial assistance and other support mechanisms, the firms abled to find new grounds after business continuity, and grow their businesses.

\subsection{Internal factor}

All the cases were quicken to uptake their management skills to steer away from business discontinuity. Case 1, 2 and 3 were attending workshop and development programs to enhance management and operational skills while Case 4 established collaborations with different technical partners to manage its technology source.

All the cases took an advantage of MARA funding scheme to build and expand operational and production ability. In general, financial resources were seen as catalyst to speedy recovery for all the cases to come out from business continuity. In Case 1, initial funding from MARA enabled the firm to jump up the operation and financed the working capital. In Case 2, a Ioan from MARA expanded the firm's processing and production ability to cater a wider market. In Case 4, a loan from MARA was used to diversify firm's business and thus, resulted in increased number of its customers.

\subsection{Resilience}

All the four cases were seen to have resilience towards business continuity. In Case 1 and Case 2, Mrs Fatihah and Mrs Sharifah found of their inner strength and inspiration in their children to restart the business. Mrs Fatihah and Mrs Sharifah felt that they needed to carry on the business so that the future of their children was not jeopardized. In Case 1, after nearly being insolvent, Mrs Fatihah was determined to restart the business even with much less equipment and machineries. In Case 2, Mrs Sharifah felt obligated to take over the business from her husband even though she had little experience in running a bakery shop. In Case 3, failing in her marriage and business gave Ms Sharifah Norizan much strength to face and cope with difficulties. In Case 4, Ms Dianty found her confidence in dealing with everyday challenges.

Resilience influenced the cases' manner in which the cases perceived business discontinuity as the making process to help them stay survive to restart the business. Thus, resilience plays an important part in repairing the business discontinuity (Gillespie, Chaboyer, and Wallis, 2007).

\subsection{Spiritual Belief}

Another key outcome in this finding was spiritual belief. All the cases professed that spiritual belief influenced the way they perceived and dealt with the business discontinuity. Spiritual belief was the caring presence and understanding of the higher power, which is God. All the cases translated the experience of grief due to business continuity into soul-searching quest. With much solace, all the cases demonstrated calmness in their business and everyday life. With calmness, all the cases started to rebuild their businesses and faced the challenges brought by it. All the cases believed that spiritual beliefs provided spaces to reflect and pull themselves together. Through spiritual belief, all the cases found healing from the pain of business discontinuity, and strength to adapt and restart the business.

As conclusion, resilience and spiritual beliefs were the added key outcomes of all the four case studies. All the cases learnt that no matter how difficult the circumstances such as business discontinuity and marital problems, these were only temporary and they can survive such episodes in life with the right attitude. Dealing with this unexpected and difficult transitional period made the cases feel more confident in their ability to cope with any situations in future.

\section{IMPLICATIONS}


This study provides a number of recommendations for practitioners and policy makers. First, current policies on financial and non-financial supports for SMEs who experienced business discontinuity should include not only financial backing but also access to psychological and social support (Singh et al., 2007). Secondly, Bumiputra SMEs should strive to improve their entrepreneurial knowledge and skills. This can be done by attending entrepreneurship courses, seminars and conventions organized by government or related parties. Bumiputra entrepreneurs also need to be alert and always keep up with the current external factors such as consumer changing buying pattern, substitute products, new competitors, and decreasing purchasing power. They also need to be aware of the various schemes and support system provided by various government agencies such as the Ministry of Rural Development, Ministry of Agriculture and government agencies including Majlis Amanah Rakyat (MARA), TEKUN and other agencies.

New economic development such as k-economy, e-commerce, and electronic marketing are examples of reforms that need to be known and studied by Bumiputra entrepreneurs. This may enrich the business management, diversification of production and marketing techniques, strengthening business networks, exploration of new business opportunities, delivering quality products and services. Bumiputra entrepreneurs should seek professional advice in dealing with business problems and challenges from parties such as MARA, FAMA, MARDI, MEDEC or business associations.

Training needs analysis among Bumiputra entrepreneurs need to be undertaken to identify critical needs faced by Bumiputra entrepreneurs in Malaysia. Studies at the state or national level need to be done as problems faced by Bumiputra entrepreneurs may vary by region, age, and background. The diversity of economic sectors such as agriculture, livestock, business, crafts, tourism actually requires different training needs analysis. Entrepreneurship education includes the skills, knowledge, and attitudes to enable individuals with problem solving skills. According to lbrahim and Soufani (2002), effective training and education can reduce business failure. Not only that, training is also very important for an entrepreneur to succeed in the competition and develop a business strategy (Webster, Walker, and Brown, 2005).

\section{CONLCUSIONS AND FUTURE RESEARCH DIRECTION}

The study broadens the understanding of factors that contribute to restarting after business discontinuity among SMEs. These factors include personality, environment, internal factors, resilience, and spiritual belief. It is expected that, the findings and discussions of this study would serve as a departing point for future research. There is substantial need to study the resilience and spiritual belief in restarting after business discontinuity among Small and Medium Enterprise (SMEs). Therefore, it is suggested that further research should be conducted to examine SMEs entrepreneur's resilience and spiritual beliefs in the context of restarting after business discontinuity. By examine these two factors; it would expand the primary view of resilience and spiritual beliefs in organizing theory literature.

\section{ACKNOWLEDGEMENT}

The study was supported by UTM Research University Grant from the Malaysia Ministry of Education, No.: R.K130000.7863.4F487, entitled "Exploring Entrepreneurial Strategic Flexibility in Resource Construction at KnowledgeIntensive Firms".

\section{REFERENCES}

[1] Abdullah, F., Hamali, J., Rahman Deen, A., Saban, G., \& Zainoren Abg Abdurahman, A. (2009). Developing a framework of success of Bumiputera entrepreneurs. Journal of Enterprising Communities: People and Places in the Global Economy, 3(1), 8-24.

[2] Aldrich, H., and Zimmer, C. 1986. Entrepreneurship through social networks. In D.L. Sexton and R.W. Smilor, eds., The Art and Science of Entrepreneurship. Cambridge, MA: Ballinger Publishing Co., 3-23.

[3] Anderson, A. R. (2005). Enacted Metaphor The Theatricality of the Entrepreneurial Process. International Small Business Journal, 23(6), 587-603. 
[4] Audet, J., \& Couteret, P. (2012). Coaching the entrepreneur: features and success factors. Journal of Small Business and Enterprise Development,19(3), 515-531.

[5] Awais Ahmad Tipu, S., \& Manzoor Arain, F. (2011). Managing success factors in entrepreneurial ventures: a behavioral approach. International Journal of Entrepreneurial Behavior \& Research, 17(5), 534-560.

[6] Azmi, A.M., Nik Hairi, O., Lee, K.Y. and Fauziah, I. (2012). Entreprenuers Success in Business: Some Critical Factors. International Business Management, 6, 369-373.

[7] Bandura, A. (1977). Self-efficacy: toward a unifying theory of behavioral change. Psychological review, 84(2), 191215.

[8] Baum, J. R., Locke, E. A., \& Smith, K. G. (2001). A multidimensional model of venture growth. Academy of management journal, 44(2), 292-303.

[9] Baumol, W.J. (1990). Entrepreneurship: productive, unproductive, and destructive. Journal of Political Economy, 98, 893-921.

[10] Benson, A., \& Han, L. (2011). Experiential learning from entrepreneurial failure.International Journal of Behavioural Accounting and Finance, 2(1), 21-39.

[11] Brockhaus, R. H. (1980). Risk taking propensity of entrepreneurs. Academy of management Journal, 23(3), 509-520.

[12] Burgelman, R. A. (1983). Corporate entrepreneurship and strategic management: Insights from a process study. Management Science, 29(12), 1349-1364.

[13] Chen, S. F. S. (2010). A general TCE model of international business institutions: Market failure and reciprocity. Journal of International Business Studies, 41(6), 935-959.

[14] Chittithaworn, C., Islam, M. A., Keawchana, T., \& Yusuf, D. H. M. (2011). Factors affecting business success of small \& medium enterprises (SMEs) in Thailand. Asian Social Science, 7(5), 180-190.

[15] Cope, J. (2011). Entrepreneurial learning from failure: An interpretative phenomenological analysis. Journal of Business Venturing, 26(6), 604-623.

[16] Corbin, J., \& Strauss, A. (1990). Basics of qualitative research: Grounded Theory procedures and techniques. Thousand Oaks, CA, US: Sage Publications, Inc.

[17] Dess, G. G., Lumpkin, G. T., \& Covin, J. G. (1997). Entrepreneurial strategy making and firm performance: Tests of contingency and configurational models. Strategic management journal, 18(9), 677-695.

[18] Dorfman, L. T., Mendez, E. C., \& Osterhaus, J. K. (2009). Stress and resilience in the oral histories of rural older women. Journal of Women \& Aging, 21(4), 303-316.

[19] Drucker, P. F. (1985). Innovative and Entrepreneurship, Practice and Principles. New York: Harper \& Row. Retrieved April, 7, 2013.

[20] Eisenhardt, K. M. (1989).Building theories from case study research. Academy of Management Review, 14(4), 532550 .

[21] Foster, S. P., \& Dye, K. (2005). Building continuity into strategy. Journal of Corporate Real Estate, 7(2), 105-119.

[22] Friedman, S. (2004). Learning to make more effective decisions: changing beliefs as a prelude to action. The Learning Organization, 11(2), 110-128.

[23] Gartner, W. B. (1989). Some suggestions for research on entrepreneurial traits and characteristics. Entrepreneurship Theory and Practice, 14(1), 27-38.

[24] Gaskill, L. R., Van Auken, H. E., \& Manning, R. A. (1993). A factor analytic study of the perceived causes of small business failure. Journal of Small Business Management, 31(4).

[25] Gillespie, B. M., Chaboyer, W., \& Wallis, M. (2007). Development of a theoretically derived model of resilience through concept analysis. Contemporary Nurse: A Journal for the Australian Nursing Profession, 25(1/2), 124-135. 
[26] Global Entrepreneurship Monitor.(2013).[Online] GEM 2013 global report. Available:http://www.gemconsortium .org/docs/3106/ gem-2013-global-report. (14 March, 2015).

[27] Hamrouni, A. D. \& Salem, A. B. (2013). Restarting after business failure: evidence from Tunisia. Universal Journal of Management and Social Sciences, 3(12), 22-39.

[28] Hisrich,R., Peters,M.\&Shepherd,D. (2005). Entrepreneurship (6th ed.). McGrawHill.

[29] Ibrahim, A. B., \& Soufani, K. (2002). Entrepreneurship education and training in Canada: a critical assessment. Education+ Training, 44(8/9), 421-430.

[30] Inyang, B. J., \& Enuoh, R. O. (2009). Entrepreneurial competencies: The missing links to successful entrepreneurship in Nigeria. International Business Research, 2(2), 62-71.

[31] Jim, E. E., \& John, W. (1996). Do small businesses have high failure rates? Evidence from Australian retailers. Journal of small business management, 34(4).

[32] Korunka, C., Frank, H., Lueger, M., \& Mugler, J. (2003). The entrepreneurial personality in the context of resources, environment, and the startup process-A configurational approach. Entrepreneurship theory and practice, 28(1), 2342.

[33] Kuratko, D.F. and Welsch, H.P. (2001). Strategic entrepreneurial growth. Harcourt College Publishers, Fort Worth, TX.

[34] Leibenstein, H. (1968). Entrepreneurship and development. The American Economic Review, 72-83.

[35] Liou, F. M., \& Yang, C. H. (2008). Predicting business failure under the existence of fraudulent financial reporting. International Journal of Accounting \& Information Management, 16(1), 74-86.

[36] Locke, E. (2000). Motivation, cognition, and action: An analysis of studies of task goals and knowledge. Applied Psychology, 49(3), 408-429.

[37] Lumpkin, G. T., \& Dess, G. G. (1997). Proactiveness versus competitive aggressiveness: Teasing apart key dimensions of an entrepreneurial orientation. Frontiers of entrepreneurship research, 1997, 47-58.

[38] Lumpkin, G. T., \& Dess, G. G. (2001). Linking two dimensions of entrepreneurial orientation to firm performance: The moderating role of environment and industry life cycle. Journal of business venturing, 16(5), 429-451.

[39] Lumpkin, G. T., \& Dess, G.G. (1996). Clarifying the entrepreneurial orientation construct and linking it to performance. Academy of Management Review, 21(1), 135-172.

[40] March, J. G. (1991). Exploration and exploitation in organizational learning. Organization science, 2(1), 71-87.

[41] Mason M. K. (2015). Research on small businesses [Online]. Retrieved from http://www.moyak.com/papers/smallbusiness-statistics.html.

[42] McGrath, R. G. (1999). Falling forward: Real options reasoning and entrepreneurial failure. Academy of Management review, 24(1), 13-30.

[43] McKenzie, B., \& Sud, M. (2008). A hermeneutical approach to understanding entrepreneurial failure. Academy of Entrepreneurship Journal, 14(2), 123-148.

[44] Miller, D. (1983). The correlates of entrepreneurship in three types of firms.Management science, 29(7), 770-791.

[45] Miller, D., \& Friesen, P. H. (1982). Innovation in conservative and entrepreneurial firms: Two models of strategic momentum. Strategic management journal, 3(1), 1-25.

[46] Minniti, M., \& Bygrave, W. (2001). A dynamic model of entrepreneurial learning.Entrepreneurship Theory and Practice, 25(3), 5-16.

[47] Murphy, G. B., Trailer, J. W., \& Hill, R. C. (1996). Measuring performance in entrepreneurship research. Journal of business research, 36(1), 15-23.

[48] Ng, H. S., \& Kee, D. M. H. (2012). The Issues and Development of Critical Success Factors for the SME Success in a developing country. International Business Management, 6(6), 680-691. 
[49] Pretorius, M. (2008). Critical variables of business failure: a review and classification framework: management. South African Journal of Economic and Management Sciences, 11(4), 408-430.

[50] Pretorius, M., \& Le Roux, I. (2011). Successive failure, repeat entrepreneurship and no learning: a case study. Journal of Human Resource Management, 9(1)

[51] Reiss,F. (2011). Why small business fail [Online]. Retrieved from http://www.publishinggame.com/art_whysmallbus inessesfail.htm.

[52] Rozell, E. J., Meyer, K. E., Scroggins, W. A., \& Guo, A. (2011). Perceptions of the characteristics of successful entrepreneurs: an empirical study in China.International Journal of Management, 28(4), 60.

[53] Schumpeter, J. A. (1935). The analysis of economic change. The Review of Economics and Statistics, 17(4), 2-10.

[54] Schumpeter, J.A. (1934). The Theory of Economic Development. Cambridge University Press, Cambridge, U.K.

[55] Schwarzer, r. (2014). Self-Efficacy: thought control of action. Taylor \& Francis, New York, USA

[56] Schwenk, C. R., \& Shrader, C. B. (1993). Effects of formal strategic planning on financial performance in small firms: A meta-analysis. Entrepreneurship Theory and Practice, 17, 53-53.

[57] Sebora, T. C., Lee, S. M., \& Sukasame, N. (2009). Critical success factors for e-commerce entrepreneurship: an empirical study of Thailand. Small Business Economics, 32(3), 303-316.

[58] Shane, S. (Ed.) (2003). A General Theory of Entrepreneurship: The Individual-Opportunity Nexus. Cheltenham, UK: Edward Elgar Publishing.

[59] Shane, S., \& Venkataraman, S. (2000). The promise of entrepreneurship as a field of research. Academy of management review, 25(1), 217-226.

[60] Shane, S., Locke, E. A., \& Collins, C. J. (2003). Entrepreneurial motivation.Human resource management review, 13(2), 257-279.

[61] Sheffi, Y., \& Rice Jr, J. B. (2005). A supply Chain View of the resilient Entreprise. MIT Sloan management review, 47(1).

[62] Shepherd, D. A. (2003). Learning from business failure: Propositions of grief recovery for the self-employed. Academy of Management Review, 28(2), 318-328.

[63] Shepherd, D. A., \& Haynie, J. M. (2011). Venture failure, stigma, and impression management: A self-verification, selfdetermination view. Strategic Entrepreneurship Journal, 5(2), 178-197.

[64] Siebert, A. 2008. The Resiliency Advantage: Master Change, Thrive Under Pressure and Bounce Back from Setbacks. Oakland, CA: Berret-Koehler Publishers.

[65] Simpson, M., Tuck, N., \& Bellamy, S. (2004). Small business success factors: the role of education and training. Education+ Training, 46(8/9), 481-491.

[66] Singh S.(2011). Experiencing and learning from entrepreneurial failure (Doctoral dissertation, University of Waikato).

[67] Singh, S., Corner, P., \& Pavlovich, K. (2007). Coping with entrepreneurial failure. Journal of Management \& Organization, 13(04), 331-344.

[68] Smith, R., \& McElwee, G. (2011). After the fall: developing a conceptual script-based model of shame in narratives of entrepreneurs in crisis!. International journal of sociology and social policy, 31(1/2), 91-109.

[69] Song, M., Podoynitsyna, K., Van Der Bij, H., \& Halman, J. I. (2008). Success Factors in New Ventures: A Metaanalysis*. Journal of product innovation management, 25(1), 7-27.

[70] Stanton, P., \& Tweed, D. (2009). Evaluation of small business failure and the framing problem. International Journal of Economics and Business Research,1(4), 438-453.

[71] Stevenson, H. H., \& Jarillo, J. C. (1990). A paradigm of entrepreneurship: Entrepreneurial management. Strategic management journal, 11(5), 17-27. 
[72] Stewart, J. J. (1989). Optimization of parameters for semiempirical methods I. Method. Journal of Computational Chemistry, 10(2), 209-220.

[73] Storey, D. J. (1994). Understanding the small business sector. Cengage Learning EMEA.

[74] Taylor, D. W., \& Thorpe, R. (2004). Entrepreneurial learning: a process of co-participation. Journal of Small Business and Enterprise Development, 11(2), 203-211.

[75] Ucbasaran, D., Shepherd, D. A., Lockett, A., \& Lyon, S. J. (2013). Life after business failure the process and consequences of business failure for entrepreneurs. Journal of Management, 39(1), 163-202.

[76] Venkataraman, S. 2003. Foreword. In S. Shane, A General Theory of Entrepreneurship. The Individual-Opportunity Nexus, xi-xii. Northampton, MA: Edward Elgar

[77] Venkataraman, S., MacMillan, I. C., \& McGrath, R. G. (1990). Progress in research on corporate venturing. Wharton School of the University of Pennsylvania, Snider Entrepreneurial Center.

[78] Wanberg, C. R., \& Banas, J. T. (2000). Predictors and outcomes of openness to changes in a reorganizing workplace. Journal of Applied Psychology, 85(1), 132-142.

[79] Webster, B. J., Walker, E. A., \& Brown, A. (2005). Small business participation in training activities. Education + Training, 47, 552-561

[80] Yin,R.K. (2009).Case study research: design and methods, $4^{\text {th }}$ ed., Thousand Oaks, California: Sage Publications, Inc.

[81] Zacharakis, A. L., Meyer, G. D., \& DeCastro, J. (1999). Differing perceptions of new venture failure: a matched exploratory study of venture capitalists and entrepreneurs. Journal of Small Business Management, 37(3).

[82] Zimmerman, B.J. (2000). Self-efficacy: an essential motive to learn. Contemporary Educational Psychology, 25(1), 8291. 
